\title{
MEDICAL TOURISM SERVICES IN THE BALTIC STATES: DENTISTRY
}

\author{
Tamara Grizane ${ }^{1,}$ Dr.oec.; Liga Jankova², Dr.oec.; Aija Sannikova, Dr.oec.; \\ Inguna Jurgelane ${ }^{4}$, Dr. oec. \\ ${ }^{1}$ Turiba University; ${ }^{2}$ Latvia University of Life Sciences and Technologies; \\ ${ }^{3}$ University of Economics and Culture; ${ }^{4}$ Riga Technical University
}

\begin{abstract}
In Latvia, the ever increasing trend of competition between the medical tourism as well as its branch dental tourism is evident. The aim of the research - to investigate the comparative advantages of the medical tourism and its services in the Baltic States. The medical tourism of the Baltic States was evaluated based on physical, economical and specialist availability and its quality. The research methodology used in the research: scientific induction and deduction, comparison, graphic, synthesis and analysis. As a result, the advantages of medical and the dental tourism of Latvia over its competitors in other Baltic states was evaluated: the comparative advantages of medical tourism in Latvia are related to the transport infrastructure advantages, the prices of dental services are similar, while a strategy is needed for a regulated influx of specialists to the specific branch.
\end{abstract}

Key words: medical tourism, dentistry, Baltic States.

JEL code: I15, R11

\section{Introduction}

Medical tourism (further MT) is one of forms of medical tourism. The term Medical tourism is attributed to the willingness of people to travel great distances in order to receive physical or mental medical treatment (OECD, 2010) and can include also dental services. It is believed that MT includes health improving procedures (Carrera, Lunt, 2010) or that it is traveling with the goal of aim of improving health (Bookman \& Bookman, 2007). Nonetheless, from an economical perspective according to the price level MT can be viewed as a more accessible service (Edelheith, 2008). Some scientists believe that medical tourism should be distanced from the health tourism (Jonson, 2010).

The overall influence of MT tourism in the economics in 2016 is evaluated at 61.12 million US dollars and is forecasted to increase by $20 \%$ until 2023 (Mordor Intelligence, 2016; Allied Market Research, 2017).

The development of MT in Latvia can facilitate the increase of tourism product export (Cabinet of Ministers of the Republic of Latvia, 2014). In addition, the development of MT in the Baltic States is a goal, which corresponds to the policy of EC in the field of tourism (European Union publications, 2011). The ability of countries to sell their products in the international markets and their ability to compete with analogue products is a market with the traditional elements of competition - price, quality etc. (Hirschey, 2008). The availability of services is influenced by the localisation of services and the purchasing power of patients, which correlates with the macroeconomic processes in the country (Elfderfield, 2017; Pollard, 2017a; 2017b).

The international competition and the change of the macro-economic environment promotes creation of medical tourism clusters - the common innovation potential inclusive networks (EK, $2002,14)$. The authors agree with the opinion that the increase of competition in the local market can further the export capability in the context of global competition (Capone, 2006; Michael, 2007). The Baltic health tourism cluster was created in 2013 (MedLT, 2013; The Baltic Assembly, 2017). Its main goal - to improve the cooperation between the tourism destination objects by sharing the suitable methods for sharing of good praxis, improving of quality and branding, by developing of the health tourism policy documents, thus concentrating the impact on the competition in the medical tourism, incl., the dentistry (Smith, 2015). 
Although in the political documents the MT in the overall tourism framework is positioned as an economically important sphere, nonetheless until now the analysis of services and support services of MT in the Baltic States, incl. the dentistry, have been insufficient. The identification of the advantages of Latvia in the specific fields have been insufficient as well.

Research question: does the medical tourism branch dentistry in Latvia has advantages in comparison with other Baltic states? The research object: medical tourism and its branch dentistry in the Baltic States. Aim of the research: to assess the advantages of Latvia's medical tourism branch dentistry industry in comparison with other Baltic States.

\section{Tasks:}

1) to study theoretical aspects of medical tourism, dentistry services and Baltic States;

2) to carry out comparative analysis of the medical tourism industry and its branch dentistry services in the Baltic States;

3) evaluate the comparative advantages of the medical tourism industry and its branch - dentistry in Latvia compared with other Baltic States.

The methods applied: the research is based on literature studies, the method of analysis as well as synthesis were used in the current study. The research methods are: monographic, comparison, abstract-logical method, synthesis and analysis, induction and deduction, statistic data analysis.

Novelty of the study: the comparative analysis of medical tourism and dentistry services in the Baltic States has been carried out.

Research sources and materials: the research includes analysis of the documents from the Baltic States, international organizations, statistical materials. The research is based on previously published reports and analysis of the official statistics, as well as authors' research on prices of services.

Research limitations: in medical tourism (MT) and its branch dentistry (further Den), there is a limited amount of available information due to the commerce secret limitations as well as due to lack of statistical data, especially in 2017. The advantages of medical tourism were analysed according to accessibility aspects - transport, prices and specialists.

\section{Research materials and methods}

MT is believed to be a constantly growing multibillion, "which makes the world compete in the aspects of the quality of medical standards, while keeping the lowest possible price for the offered medical services" (Lunt et al., 2016: 40; Sandberg, 2017). This tourism branch is most popular in high income countries (the US, Canada and Western-Europe countries), especially in cases, when the inland health insurance doesn't cover whole health treatment needs. In these cases, the citizens often choose to buy high quality low-cost medical services abroad.

Different sources can be used in the comparison of MT services and evaluation, for instance, the ranking of the medical industry dentistry - Global Clinic Rating (GCR) (MTQUA, 2014). It can be concluded that the number of the best dental clinics is uneven (in Europe - 14, North-America - 2, Vietnam, India and Philippines - 3, while the dominating country in the dental industry is Hungary with 450 clinics (Global Clinic Ranking survey, 2016). Meanwhile dental tourism dental implant services are provided in Croatia, Poland, Egypt, Thailand, Turkey, Labanon, Mexico, the United Arab Emirates and India. In the hospital rankings (Global Clinic Ranking survey, 2016). The service quality is also affected by the trends in the provision of specialist training, which is led by 
such universities as the University of Hong Kong, The University of Michigan, Karolinska Institutet of Sweden (QS World University Rankings..., 2016).

In order to evaluate the MT in the Baltic States, the country specific medical tourism and its services' criteria was defined, thus allowing to determine the competitiveness of the specific country. These include: the number of inhabitants per one dentist, age structure of dentists, organisation of dental education, price of services, availability, compliance of the treatment standard etc. (Kotulic, Lencova, 2010; Cernikovaite, Mameniskis, 2015; Smith, 2015). There are 46 medical treatment institutions in Latvia which have registered for MT service provision; however, none of these or any other of the institutions in the Baltic States are ranked among the world's best service providers.

Although medicine clusters in the Baltic States identify the specific MT resources in the common regional health tourism brand creation in the Baltics (Smith, 2014; 2015), yet in this research there is not enough attention paid to the MT branch - dentistry. It is acknowledged that the MT is a specific form of patient mobility, which is determined by multiple factors: cost of services; travel costs; quality anticipation; language of communication; previous experience of the individual. This indicates the importance to evaluate the MT impacting factors. Based on the acquired information, authors analysed the MT in three separate blocks: (1) according to physical availability; (2) economical accessibility; (3) availability and quality of the specialists.

\section{Research results and discussion}

Physical accessibility (transport). The Baltic countries are located in the geographical centre of Europe, thus it is easy to reach them by plane from any European country. Main airports are located in the capitals: Riga, Vilnius and Tallinn. However, there are also smaller regional airports where international airlines operate - Kaunas and Palanga in Lithuania and Tartu in Estonia. However, when comparing it with other Baltic countries, the Riga airport is far superior, because according to the information collected by the Airport Council International (ACI), it is included in the airport group with the overall serviced client capacity of 5-10 million per year with a growth index of 9.6, which significantly exceeds even the average results of airports in Europe (BNN, 2017). Authors underline that it can be clearly observed in the World Economic Forum Report: according to the quality of air transport infrastructure, Latvia is ranked $51^{\text {st }}$, Lithuania $78^{\text {th }}$, while Lithuania $53^{\text {rd }}$ (Wold Economic Forum Report, 2017).

International train routes from Riga are to St.Petersburg, Moscow, Pskov in Russia and border town Valga in Estonia. Trains go from Vilnius to St.Petersburg, Moscow, Kaliningrad in Russia and Warsaw in Poland. From Tallinn, trains depart to Moscow. One has to mention that there are good bus services between the largest cities of the three Baltic States and the neighbouring countries. Land and port infrastructure ranks Latvia $41^{\text {st }}$, Lithuania $32^{\text {nd }}$, while Estonia $36^{\text {th }}$ (Wold Economic Forum Report, 2017).

The MT arrivals of Estonia, in comparison to that of Latvia (Table 1) is significantly larger, namely by 1.65 million arrivals and 669US $\$$ millions in tourism receipts and in comparison to Lithuania by 847 million arrivals and 351 US\$ millions in tourism receipts. One of the reasons why the Medical tourists commonly choose Estonia is related to the tourism infrastructure, according to which Estonia is ranked $22^{\text {nd }}$, Latvia $48^{\text {th }}$, while Lithuania $58^{\text {th }}$ (Wold Economic Forum Report, 2017). 
Dental care target markets for Latvia are the United Kingdom, Norway, Finland, Ireland, Sweden, for Estonia - Scandinavia (esp. Finland) and Russia, while for Lithuania - Germany, Poland, the UK, Scandinavia, and Ukraine. When comparing the time spent on travelling with airplane to Latvia and while taking into account the transport waiting time, according to the authors' calculations time spent by the MTs from the Scandinavian countries reaches $3 \mathrm{~h} 30 \mathrm{~min}$ to $5 \mathrm{~h} 30 \mathrm{~min}$ by air, by train/ferry - $17 \mathrm{~h} \mathrm{-} 24 \mathrm{~h} 40 \mathrm{~min}$, ferry/car - $6 \mathrm{~h} 17 \mathrm{~min}-20 \mathrm{~h} 29 \mathrm{~min}$. When travelling by air from the UK, the travel rime reaches $2 \mathrm{~h} 45 \mathrm{~min}$, while train/bus $-32 \mathrm{~h} 38 \mathrm{~min}$. Time spent travelling from Estonia to Lithuania from Scandinavian countries, in comparison to Latvia, is close with an average interval of $1 \mathrm{~h}-2 \mathrm{~h}$.

Table 1

Comparison of descriptive economic activity data in the Baltics States

\begin{tabular}{|c|c|c|c|}
\hline \multirow{2}{*}{ Metric } & \multicolumn{3}{|c|}{ Baltic States } \\
\hline & Latvia & Lithuania & Estonia \\
\hline Population (01.01.2017) & 1937444 & 2854649 & 1315944 \\
\hline GDP per capita, 2016 (EUR) & 15231 & 12329 & 17853 \\
\hline International Tourist Arrivals (million) & 1793 & 2296 & 3143 \\
\hline Tourism Receipts (US\$ million) & 867 & 1,185 & 1,536 \\
\hline Indicator of competitiveness $(2010=100 \%), 2017$ & 103.1 & 101.4 & 104.8 \\
\hline Global Competitiveness Index (GCI), 2016-2017* & 49 & 35 & 30 \\
\hline Travel \& Tourism Competitiveness Index (T\&T)** & 54 & 56 & 37 \\
\hline Health expenditure per capita, 2016 USD, PPP Total & 1466 & 1970 & 1989 \\
\hline - Government/Compulsory & 828 & 1319 & 1513 \\
\hline - Voluntary/Out -of-pocket & 639 & 652 & 476 \\
\hline Standard Vat rates ( \%) & 21 & 21 & 20 \\
\hline $\begin{array}{l}\text { - Medicines, Medical Equipment for Personal use of } \\
\text { the Disabled }(\%)\end{array}$ & 12 & 5 & 9 \\
\hline - Transport ( \%) & 12 & 9 & 20 \\
\hline - Hotel accommodation ( \%) & 12 & 9 & 9 \\
\hline - Restaurant and catering services ( \%) & 21 & 21 & 20 \\
\hline Dentist per 100000 inhabitants, 2015 & 72 & 91 & 94 \\
\hline Gross monthly wage of dentists, 2017 & 981 & 1151 & 1473 \\
\hline
\end{tabular}

* Rank out of 136 (2017); ** Rank out of 141 (2015)

Source: designed by the author according Global Competitiveness Report, 2016; OECD Economic Outlook, 2016; World Bank, 2016; EUROSTAT, 2017; Health at a Glance 2017..., 2017; Health Statistics and a Health..., 2017 ; Privaciu odontologijos kliniku, 2017; UNWTO, 2017

One exception is the travel from Finland to Estonia, which is only $35 \mathrm{~min}$ by air or $2-3 \mathrm{~h} 30 \mathrm{~min}$ by a ferry. However, the distance to Estonia is longer and more time consuming than a travel from other EU countries. Travels between the Baltic States by car take $2 \mathrm{~h} 30-3 \mathrm{~h}$, while by air $50-56 \mathrm{~min}$. Authors conclude that although the time consumption varies, nonetheless Latvia owing to its geographic location is in a more favourable position.

Economical accessibility. Many researchers, whom authors agree with, believe that the MT (dental treatments) are chosen by clients in the bordering region countries because of economic accessibility (Osterle et al., 2009; Onesimo Cuamea, et al., 2017). One of the reasons is GDP per capita (Table 1), which drives the flow of MT to countries with economically balanced expenses, the second one - health expenditure per capita (Uçak, 2016). Costs of medical care in the target country in most cases is related to the GDP of the given country, and the low administrative and medical costs increase the accessibility of both the MT and the medical services. 
Among the Baltic States, Lithuania, although characterized by lower GDP per capita, is investing in MT almost as much as Estonia and by $504 €$ more than Latvia. Although the GDP per capita of Estonia is $17853 €$ (2016), the overall investment of the state is the largest among the Baltic States. An important part of the MT services' prices are the VAT rates, which in Latvia are the highest (Table 1). This also applies to the services affecting tourism - transport, accommodation, restaurant and catering services. This also affects the medical tourism, which in Latvia by 3 and $7 \%$ higher than in Estonia and Lithuania.

Authors believe that the price is one of the most important factors in the entrepreneurship environment. In the dental branch, authors analysed prices of six services - visitation, tooth filling, placement of tooth crown, insertion of implant, extraction of impacted tooth, as well as dental hygiene. The comparison of dental service prices in the Baltic States (Table 2) show that the prices in Baltic States do not differ significantly; however, the tooth extraction and tooth implantation services are cheaper in Latvia, while the tooth hygiene - in Lithuania.

Average prices of dentistry services in the Baltic States

\begin{tabular}{|l|c|c|c|}
\hline \multirow{2}{*}{\multicolumn{1}{|c|}{ Services (C) }} & \multicolumn{3}{c|}{ Baltic Countries } \\
\cline { 2 - 4 } & Latvia & Lithuania & Estonia \\
\hline Visitation & $20-25$ & Free -15 & Free $-35-40$ \\
\hline Tooth filling & $55-65$ & $50-70$ & $23-55$ \\
\hline Placement of crown & $320-335$ & $220-400$ & $325-500$ \\
\hline Insertion of implant & $665-700$ & $550-1400$ & $1300-1500$ \\
\hline Extraction of impacted tooth & $55-60$ & $70-150$ & $60-150$ \\
\hline Dental hygiene & $45-70$ & $30-60$ & $65-80$ \\
\hline
\end{tabular}

Source: designed by the author according Baltic States company websites. The average salary of dentists in the Baltic States based on price surveys and official website of dental service providers

The MT prices are attributed to a wider range, for instance, in Finland tooth implants (price 1.900-2.400€) are not covered by state insurance, therefore the service is more favourable in Estonia. However, as it is pointed out by the head of Lithuania medical tourism cluster Mr Grazvidas Morkuss (Grazvydas Morkus), dental treatment services in Lithuania are up to 12 times more affordable than those in Norway, which, as a result, drives the increase of Scandinavian medical tourists.

In Latvia, reliable statistics on MT is not available. Conclusions can be drawn that $11 \%$ of the allocated resources by the National Health Service in Latvia are used for dental treatment (Republic of Latvia. Regulations No.1036, 2004).

Availability of specialists and quality. The number of inhabitants of Estonia, in comparison to those of Latvia and Lithuania is smaller (Table 1), the number of available dentists per 100000 citizens than elsewhere in the Baltic States, accordingly - par 22 und 3. It is more common for women to be employed as dentists - Estonia and Latvia - 87 \%, Lithuania - 83 \% (2013); meanwhile, for instance, in Switzerland and Italy, the female specialists amount to only $28 \%$ und $34 \%$ correspondingly (Kravitzobe, Bullock, Cowpe, et al., 2015). More than half of those working in the dentistry in Latvia (as well as in other Baltic States) are older than 50 years: in Latvia $40.4 \%$ are in the age group 50-64 years, $11 \%$ - older than 64 years (Latvia. Statistics in Brief 2017 , 2017). The gross monthly wage of dentists (2017) in Latvia (Table 1) that is $170 €$ less than in Lithuania and $492 €$ less than in Estonia. The resulting outcomes of such conditions are the workemigration (Balazs, 2012), which is backed by a survey indicating that in Lithuania during the 
economic crisis (2010) $26.9 \%$ of the dentistry students planned to work abroad (Janulyte, Puriene, Petrauskiene, et al., 2011) with similar situation in Latvia.

In Lithuania, dental education is offered by two universities - Vilnius University and Lithuanian University of Health Sciences in Kaunas, Centre of Dentistry and WHO Collaborating Centre in Continuing Dental Education; in the Riga Stradins University Institute of Stomatology in Latvia; in Estonia - University of Tartu, in which the studies are fully funded by the state. Nonetheless, the overall number of prepared qualified dentists is not sufficient for the growing demand. Authors conclude that dentist qualifies under the ISCO 08 with the code 226:2261. The Euro Health Consumer Index (EHCI) 2016 is made up of six sub-disciplines. As no country excels across all aspects of measuring a healthcare system, it is of interest to study between the six-subdisciplines out of which accessibility (waiting times for treatment) when summing together give the following ranks to the Baltic States $(n=35)$, where Latvia is ranked 29, Lithuania 27 and Estonia 17 (Bjornberg, 2017).

\section{Conclusions, proposals, recommendations}

1) Medical tourism is one of the forms of health tourism and a growing industry worldwide. MT is developing also in the Baltic States, while the target markets of the Baltic States tend to overlap.

2) According to the physical accessibility of MT, Latvia has the comparative advantages among the Baltic States, which increases the overall accessibility of medical services according to the time factor. Nonetheless, the country is lagging behind other Baltic States according to the ground and port infrastructure rankings ( $41^{\text {st }}$ place), which should be further developed.

3) Overall, the tourism infrastructure ranks highest among the Baltic States; however, Estonia manages to gain the largest amount of income. One of reasons behind such situation is that Estonia (same as Lithuania) have advantages in terms of lower VAT rates on transport, accommodation, restaurant and catering services costs as well as lower medical tourism services and dental services costs. Medical tourism in Estonia is influenced by a more arranged environment of employment and a larger state funding for education in the field of dentistry, while in Lithuania - by more financing for health-care system.

4) The average costs of dental services in the Baltic States are prone to large differences; therefore, MT advantages for Latvia are related to the transport infrastructure advantages, which make the services more accessible (time and travel costs).

5) By developing the Baltic tourism MT cluster, Latvia and other Baltic States can promote influx of new specialists in the specific field and has the potential to increase the competition, thus increasing the overall quality of services and innovative services.

\section{Bibliography}

1. Balazs, P. (2012). Dentists' Workforce in Hungary and International Migration. Fogorv Sz. Vol.105(2), pp. 77-85.

2. Bjonberg, A. (2017). Euro Health Consumer Index 2016. Report. Health Consumer Powerhouse, p. 100.

3. BNN (Baltic News Network) Riga Airport becomes part of TOP 5 of Europe's rapidly growing airports. September 20, 2017. Retrieved: http://bnn-news.com/riga-airport-becomes-part-of-top-5-of-europe-srapidly-growing-airports-171922. Access: 10.02.2018.

4. Bookman, M., Bookman, K. (2007). Medical Tourism in Developing Countries. Basingstoke: Palgrave Macmillan, pp. 12.

5. Cabinet of Ministers of the Republic of Latvia (2014). Cabinet Regulation No.326 'Latvia tourism development guidelines for 2014.-2020.' Retrieved: https://likumi.lv/doc.php?id=267332.

Access: 13.01.2018. 
6. Capone, F. (2006). Systemic Approaches for the Analysis of Tourism Destination: Towards the Tourist Local Systems. In L. Lazzeretti \& C. S. Petrillo (Eds.), Tourism Local Systems and Networking, pp. 7-23. Oxford, Amsterdam: Elsevier.

7. Carrera P. , Lunt (2010). A European Perspective on Medical Tourism: The need for a knowledge base. International Journal of Health and Services, Vol. 40(3), pp. 469-84.

8. Cernikovaite M. E., Mantas Jonas Mameniskis, M.J. (2015). Medical Tourist' Expectations when Choosing Lithuania for Health care Services. Social Transformations in Contemporary Society, Vol.3, p39.

9. CSB (Central Statistics Bureu of Latvia) (2015). Baltijas valstis. Retrieved: http://www.csb.gov.Iv/sites/default/files/skoleniem/LV_ES/baltijas_valstis.pdf. Access: 15.01.2018.

10. Edelheit, J. (2008). Defining Medical Tourism or not? Medical Tourism Magazine, Vol.5, pp. 9-10.

11. EK (European Commission) (2002). Regionale Cluster in Europe. Beobachtungsnetz der europäischen kmU,3. Luxemburg: Amt für amtliche Veröffentlichungen der Europäischen Gemeinschaft.

12. Elfderfield, G. (2017). For Healthcare Leader (HSJ) Retrieved: https://www.hsj.co.uk/grahamelderfield/1546716.publicprofile. Access: 30.01.2018.

13. European Union publications (2011). 'Directive 2011/24 of 9 March 2011 of the European Parliament and the Council on the application of patients' rights in cross-border healthcare'. Official Journal of the European Union, L 88, p. 45.

14. Eurostat: website. (2017). Health personnel (excluding nursing and caring professionals). Retrieved: http://appsso.eurostat.ec.europa.eu/nui/submitViewTableAction.do. Access: 02.02.2018.

15. Global Clinic Ranking survey (2016). TOP Dental Clinic Rankings for 2016. Retrieved: https://gcr.org/top/dental. Access: 15.01.2018.

16. Health at a Glance 2017: OECD Indicators (2017). Health expenditure per capita, 2016. OECD publishing, p. 4.

17. Health Statistics and a Health Research Database (2017a). Gross monthly wage of dentists. Retrieved:

18. http://pxweb.tai.ee/PXWeb2015/pxweb/en/04THressursid/04THressursid_06THTootajatePalk/TT06.px/tabl e/tableViewLayout2/?rxid=8ddacc78-b02a-4765-9501-4cc63c152d4e. Access: 10.02.2018.

19. Hirschey M. (2008). Managerial Economics. - Mason, Ohio: Thomson/South-Western, 791 p.

20. Janulyte, V., Puriene, A., Petrauskiene, J., Peciuliene, V., Benzian, H.(2011). International migration of Lithuanian oral health professionals: a survey of graduates. Int Dent J. Vol.61(4), pp. 224-230. doi: 10.1111/j.1875-595X.2011.00062.x.

21. Kravitzobe, A.S., Bullock, A., Jon Cowpe, J., Barne, E. (2015). EU Manual of Dental Practice 2015. Edition 5.1. The Council of European Dentists. UK: Cardiff University, Wales. P. 420.

22. Kotulic, C., Lencova, E. (2010). Konkurencni prostredi a konkurenceschopnost zubnich ordinaci $v$ CR. Konkurence - Teoreticke a prakticke aspekty. Sbornik prispevku z pracovni konference s mezinarodni uscasti, pp. 166-169.

23. Latvia. Statistics in Brieth 2017. Practising medical specialists by age and speciality http://www.csb.gov.Iv/sites/default/files/nr_04_latvia_statistics_in_brief_2017_17_00_en.pdf

24. State Inspection of the Republic of Latvia. Official website (2017). Medical Institutions Registered for Medical Tourism Services. Retrieved: http://www.vi.gov.Iv/uploads/files/medicinas \%20turisms_15122017.pdf. Access: 05.01.2018.

25. Lunt, N., Horsfall, D., Hanefeld, J. (2016). Medical tourism: A snapshot of evidence on treatment abroad. Maturitas, Vol. 88, pp. 37-44.

26. Medlt (2013). Cooperation Between Baltic States Medical Tourism Clusters and Associations Established. Retrieved: http://www.medlt.com/EN/menu/news/cooperation-between-baltic-states-medical-tourismclusters-and-associations-established. Access: 02.02.2018.

27. Michael, E. J. (2007). Micro-Clusters and Networks: The Growth of Tourism (1st ed.). Oxford: Elsevier Science.

28. Mordor Intelligence (2016). Global Medical Tourism Market - Growth, Trends \& Forecast (2016-2021). Retrieved: https://www.mordorintelligence.com/industry-reports/medical-tourism market?gclid=CjOKEQjw3_HOBRDa7NbDqdudqMEBEiQAvLBbohYsuWMyaKpm7NWn0-oFtmnLNTfbtIOBikgxYQLIqQaAsRv8P8HAQ. Access: 10.01.2018.

29. MTQUA (Medical Tourism Travel Quakity Alliance) (2014). Medical Tourism Certification from MTQUA. Retrieved: https://www.mtqua.org/medical-tourism-certification/. Access: 15.01.2017.

30. OECD (2010). Health Accounts Experts, Progress Report. Trade in Health Care Goods and Services Under the System of Health Accounts. Paris: OECD, p. 4.

31. OECD Economic Outlook (2016). OECD. Retrieved: http://www.oecd-ilibrary.org/ Access: 5.01.2017

32. OECD Health Statistics 2017: website. (2018). OECD Health Statistics 2017 - requested Data (November 2017). Retrieved: http://www.oecd.org/health/health-data.htm. Access: 02.02.2018.

33. Onesimo Cuamea, V., Jorge, C., Morgan M., Ario, r., Estrada, G. (2017). Dental Tourism: Key factors that Influence the Selection of a Dental Clinic. International Journal of Advanced Research Vol.5 (2), pp. 27132721.

34. Osterle, A., Balazs, P. , Delgado, J. (2009). Travelling for teeth: Characteristics and perspectives of dental care tourism in Hungary. British dental journal official journal of the British Dental Association: BDJ online Vol.206(8), pp. 425-428. 
35. Pollard, K. (2017a). If you don't like change, get out of the private healthcare sector now. Retrieved: https://www.privatehealth.co.uk/industry/blog/ \%E2 \%80 \%9Cif-you-don \%E2 \%80 \%99t-change-get-outprivate-healthcare-sector-now \%E2 \%80 \%9D-1153809/. Access: 30.01.2018.

36. Pollard, K. (2017b). How to Create a Unique Value Proposition in Medical Tourism. Presentation from Public Healthcare Summit 2017. International Medical Travel Journal (IMTJ). Retrieved: https://www.imtj.com/. Access: 30.01 .2018$.

37. Privaciu odontologijos kliniku mokamas didziausias vidutinis darbo uzmokestis 2017 m., Eur/mèn. [average sallary in private dental clinics in 2017 EUR/per month] Retrieved: https://www.vz.It/paslaugos/2017/06/03/didziausios-algos-privaciose-odontologijos-klinikose. Access: 05.01.2018.

38. QS World University Rankings by Subject 2016 - Dentistry (2018). Retrieved: https://www.topuniversities.com/university-rankings/university-subject-rankings/2016/dentistry. Access: 15.01.2017.

39. Republic of Latvia. Regulations No.1036 of the Cabinet of Ministers of April 13, 2004 'Health Care Organization and Financing Procedures' issued by the Cabinet of Ministers on 18 January, 2005. (21.12.2004). Latvijas Vestnesis Nr.9, 2005. 18.janv.

40. Sandberg, D. (2017). Medical Tourism: An Emerging Global Healthcare Industry. International Journal of Healthcare Management, Vol. 10(4), pp. 281-288. 